\title{
Diversity and Habitat Association of Birds in a Vindhyan Gorge of Kekariya, Rajasthan, India
}

\author{
Ashvini Kumar Joshii ${ }^{1 *}$, Chhaya Bhatnagar ${ }^{2}$ \\ ${ }^{1}$ Wildlife and Conservation Research Laboratory, Department \\ of Zoology, M.L.V. Government College, Bhilwara, \\ Rajasthan. \\ ${ }^{2}$ Aquatic Toxicology and Wildlife Laboratory, Department of \\ Zoology, Mohan Lal Sukhadia University, Udaipur, \\ Rajasthan \\ Study Area: Vindhyan Gorge of Kekariya, \\ Bhilwara, Rajasthan \\ Coordinates: N $25^{\circ}$ o8' 21.48” E $075^{\circ}$ o1' 52.52'
}

Key words: Avifauna, Threats,

\section{Abstract}

Vindhyan gorges are spreaded in the south east part of Rajasthan. Geologically the Vindhyan gorge of Kekariya, Rajasthan is kept in Bhander group under Vindhyan supergroup having rocks of sandstone, shales and limestone. We studied the diversity of the avifauna of this gorge from 2013 to 2016 using line transect method. Total 82 species of birds were recorded during the present study. Out of these, 64 species were resident and 18 species were migratory. Birds showed their habitat preference for different parts of the gorge. Raptor birds dominated all other birds. Illegal woodcutting, over grazing and people's ignorance towards conservation were some of the threats identif ied to the gorge biodiversity.

\section{Introduction:}

Canyons and gorges are the deep and narrow valleys having wall like steep valley sides. These are formed because of regular down cutting of the valley by the fluvial cycle of erosion and recession of waterfalls (Singh, 2015). The Vindhyan range is located in the south-east part of the Rajasthan state of India in Dholpur, Bharatpur, Karauli, Sawai Madhopur, Bundi, Kota, Bhilwara and Chittorgarh districts. The Vindhyan range gives rise to many rivers as Chambal, Kali Sindh, Parwan, Menali, Berach etc. These river flows from the deep gorges, a characteristic of the Vindhyas. The Chambal River flows in the deep Vindhyan gorge in the Hadoti region of Rajasthan. Several microecosystems are found in the gorges due to the differences in humidity, sunlight and other typical abiotic factors. This diversity of habitat and regional micro-ecosystems make gorges richer in vegetation and the concerned fauna (Grant, 2005; Mowbray \& Henry, 1968).The almost undisturbed ecology and riparian vegetation of the gorges also favours the rich biodiversity. The Kresna gorge of Bulgaria was reported to harbour 232 avian species which is indeed $58 \%$ of the total Bulgarian avian fauna (Hubenov, 2012). Keeping such figures and facts in mind many of the gorges outside India, have been protected by laws as Protected Areas.

Biodiversity of the birds of the gorges have been studied worldwide (Kopij, 2013; Spence et al., 2011; Patten et al., 2006; Nikolov \& Spasov, 2005; Shurulinkov \&
Nikolov, 2005; Hornsby, 1997; Taylor, 1989; Parnell \& Quay, 1964) but no scientif ic study has been done in India besides a single checklist of the birds on Vindhyan gorges (Sharma and Singh, 2006). In the present study, we attempted to bring to the fore the diversity of the birds in this wonderful area accompanied with the threats and conservation suggestions for the habitat.

\section{Materials and methods:}

Study Area: Bhilwara district is located in the midsouthern part of the Rajasthan state. The Vindhya Range passes from the south-east part of the district through Mandalgarh subdivision. The gorge of Kekariya is situated $15 \mathrm{Km}$ south west from headquarters of Mandalgarh subdivision. It has its name from the neighbouring village Kekariya. This gorge is 1560 meter in length with varying width along its length. During Monsoon, water flows in the gorge in the form of many small rivulets and streams. Although these streams disappear after monsoon but small underground streams confirm availability of water in the gorge round the year. Water accumulates locally in some pits in the gorges and supports the wildlife. The average rain fall in the area is $735 \mathrm{~mm}$ which is above the mean annual rainfall of entire Rajasthan as well as is higher than other parts of Bhilwara district. The average temperature is $25.8^{\circ} \mathrm{C}$ The vegetation of the gorge is chiefly dry deciduous type dominated by Anogeissus pendula (Dhok), Boswellia serrata (Salar), Prosopis cineraria (Khejri), Acacia 
leucophloea (Khejda) Senegalia catechu (Khair), Dalbergia sissoo (Shisham), Butea monosperma (Dhhak) and Ziziphus mauritiana (Ber).

The study was accomplished in and around the Kekariya gorge of Vindhyan mountain range,from winter 2013 to summer 2016. Data were collected during early morning hours from 7:00 to 9: oo in winters and 6:00 to 8:00 in summers on three season basis i.e., summer, monsoon and winter. Random visit between the seasons were also made. Line transect method (Bibby et al., 1998) was followed to study the birds. Transects of different lengths were laid in the bottom and terrace of the gorge. The length was $1560 \mathrm{~m}$ in the bottom and $1380 \mathrm{~m}$ on the terrace of the gorge. Walking on transect with uniform pace, the birds seen on either side of the transect were recorded. The birds were seen and photographed using Celestron binoculars (8x42) and Canon 1200 DSLR camera with 55-250 mm zoom lens. Call notes of birds were also used for locating and identifying birds. Garmin etrexzo GPS was used to record the geographical coordinates of a particular location. The birds were identified and listed using field books (Grimmett et al., 2011). All the birds were categorized on the basis of trophic guild based on Ali and Ripley (2007) and field observations done. Although this gorge does not have a high altitude but an attempt has been made to show the distribution of the birds according to their preference to stay in gorge. Abbreviation "IG" is used for "In gorge" and RG is used for "Roof or Terrace of the gorge". The residential status of the birds was categorized as "summer migratory" "winter migratory", "passage migratory" and "resident". The birds seen regularly in the study area were categorized as "resident"; birds encountered only in summer and winter seasons were kept under "summer migratory" and "winter migratory" and birds encountered only once or twice during the study period were considered as "passage migratory". We calculated the Relative diversity (RD) of the birds of dominating families using the following formula:

\section{$\mathrm{RD}=\quad$ Number of species in a family $\times 100$ Total number of species}

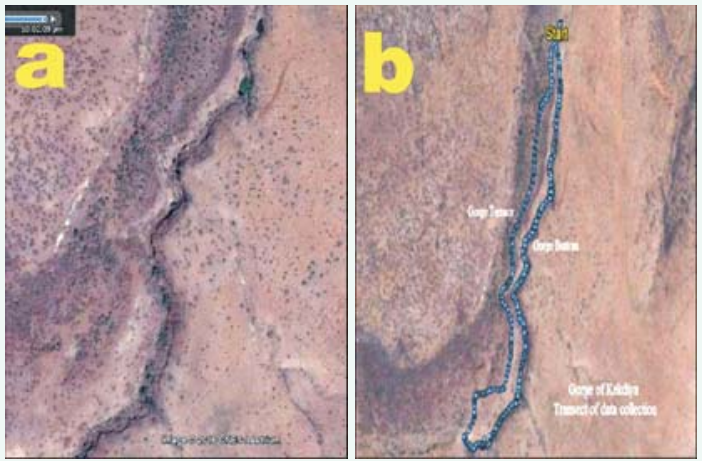

Figure 1: Googleearth image of the gorge showing; a) Vindhyan gorge of Kekariya, b) the transect of study

\section{Results}

We recorded total 82 species of 36 Families during the study period (Table: 1 ). In the previous study (Sharma \& Singh, 2006) 30 species of the birds were reported in the same Vindhyan gorge. Out of the 82 species, 64 species were resident, 15 were winter migratory and 3 were summer migratory. As per the IUCN red list 2015, three bird species of the gorge, Long-billed vulture, Gyps indicus is critically endangered, Egyptian vulture, Neophron percnopterus is endangered and Wooly necked stork, Ciconia episcopus is vulnerable. From the guild point of view $41.46 \%(\mathrm{n}=34)$ birds were insectivorous, 23.17\% $(\mathrm{n}=19)$ birds were Omnivorous, $21.95 \%(\mathrm{n}=18)$ were Carnivorous, $8.54 \%(n=7)$ were Grainivorous, $3.66 \%(n=3)$ were Frugivorous and $1.22 \%(\mathrm{n}=1)$ was Nectarivorous. Cisticolidae is the biggest family of the area (RD-9.76) followed by Accipitridae with (RD-7.32). Ten species of raptors were recorded here in this gorge.

\section{Discussion:}

The Gorge of Kekariya supports a variety of life in its ecology and functions like an ecological corridor. Corridors are the linear path of habitat that permits movement of animals through landscapes (Puth \& Wilson, 2001). The gorge of Kekariya provides a safe route for movement and other vital activities for animals away from human disturbances. Availability of food and water, breeding sites and diverse habitats make gorge an excellent stay site for the birds. High cliffs, burrows, crevices, trees with thick trunks, dry tree trunks, patches of long grass, exposed rocks, thorny vegetation and high density of plants and accumulated water in the gorge are some varieties of habitats suitable for different bird species. Cormorants, herons, egrets and kingf ishers are attracted towards the gorge because of occurrence of small fishes and small invertebrate like crab and molluscs in water. Humidity, availability of grass and flowering plants affect the population of insectivorous birds in any habitat as suggested by Joshi \& Bhatnagar (2015). Flowers of trees and grass of the gorge attract insects which in turn invite insectivorous birds to the gorge. This is why insectivorous birds make the highest proportion (41.46\%) among the total bird species (Fig.: 2). Thick trunks are suitable for the birds which make hole-nest such as Roseringed Parakeet Psittacula krameri, Common Myna Acridotheres tristis, Brahminy starling Sturnus pagodarum and Indian Roller Coracias benghalensis.

A significant aspect of Kekariya gorge biodiversity is the breeding of critically endangered Long-billed vultures and endangered Egyptian vultures. High cliffs and ruins are preferred for nesting by the vultures (Rahmani, 2015; Manchiryala \& Medicheti, 2016). Availability of high cliffs in the gorge of Kekariya supports these threatened bird species. Vultures scavenge the dead carcasses and 


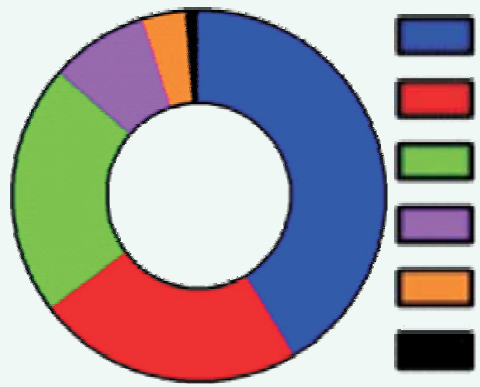

Insectivorous Omnivorous Carnivorous Grainivorous Frugivorous Nectarivorous

Figure-2: showing proportion of birds of different guild in the study area

remnants of prey of carnivore animals left in the gorge. In summers, water around the gorge almost dries up and then water inside the gorge becomes a life line for the animals. Availability of water in the gorge is like an oasis for these animals. Many birds like Ashy Crowned Sparrow-Lark Eremopterix griseus, Eurasian Collared Dove Streptopelia decaocto, Laughing Dove Streptopelia senegalensis, Spotted Dove Streptopelia chinensis and Babblers which usually avoid their stay in the gorge, come to the gorge floor for water in summers. Presence of small birds, rodents and small mammals support the presence of raptor birds. Different owl and eagle species get their food from the gorge. Birds like house sparrow Passer domesticus and house crow Corvus splendens were not seen in the area as these birds prefer human habitations and are present in the nearbyvillage.

Wood cutting for fuel and fodder purposes, overgrazing leading to denudation of the land and lack of awareness of people for biodiversity conservation were some pressing problems of this gorge. Gorge biodiversity is dependent on rainfall for their water requirement. So sometime it becomes critical factor for the gorge ecosystem as scarcity of water leads to change in vegetation and habitat alteration (Quinn et al., 2005). During the present study in year 2015 the number of birds was negatively affected due to the low rainfall. Fuel wood collection and overgrazing are identified as the principle threats to the biodiversity (Chanie \& Tesfaye, 2015). In Samaria gorge one of the many threats identified was overgrazing by the domestic goats which had destroyed the natural regeneration of important plants in the area (Spanos et al., 2008). We found the similar biotic pressure of overgrazing on trees which remained dwarf only due to overgrazing. Many stunted trees of Anogessius pendula can be seen in the gorge which are not attaining their height because of overgrazing by the livestock. Thus the use of forests for livelihood such as firewood and fodder collection, overgrazing is pushing the biodiversity towards a decline. These socio-economic changes have been identified as a threat for the biodiversity (Jalilovaa, 2013). In Kekariya, the communication between the villagers and the authorities seems a neglected aspect that results into lack of cooperation from the public side. NGO's had prepared check dam in the gorge to prevent soil erosion and for water conservation but no support or initiative was taken by villagers to maintain them at their own. Similar problem was reported from Lazer Canyon of Eastern Serbia where conservation efforts had lost the directions without insufficient co-operation and communication between organizations (Grujcic et al., 2008).

The findings of our study suggest that gorge natural forests must be conserved to prevent the genetic biodiversity loss. It is the habitat and breeding site of the birds as well as many mammals. Grazing should be planned in such a way that it could be done in different patches of the habitat alternatively. So that it would divide the pressure and growing plant will get time to regenerate. Reforestation is also strongly recommended. The conservation should be planned and managed in such a way to ensure the willful participation of local people and also fulf ill their daily requirement from the forest.

Acknowledgements:Authors express their gratitude to University Grant Commission, New Delhi for financial assistance of the research work. Authors are also thankful to Dr. S.K.Sharma, ACF, Udaipur and Shri Rakesh Chourey, Ecologist, Mandalgarh (Bhilwara) for theirvaluableadvice and help in research. .

\section{References:}

Ali, S., \& Ripley, S.D. (2007): Handbook of the birds of India and Pakistan. Publisher: BNHS and Oxford University Press.

Bibby, C., Jones, M. \& Marsden, S. (1998): Expedition Field Techniques Bird Surveys. Publisher: The Expedition Advisory Centre, Royal Geographical Society. 1 Kensington Gore, London $\mathrm{SW}_{7} 2 \mathrm{AR}$.

Chanie, S., \& Tesfaye, D. (2015): Threats of biodiversity conservation and ecotourism activities in Nechsar National Park, Ethiopia. Int.J. Biodivers. Conserv, 7(3);130-139.

Grant C. (2005): Carnarvon National Park management plan. (ISSN-1037-4698)

Grimmett, R., Inskipp, C., \& Inskipp, T. (2010): Birds of Indian Subcontinent. Publisher: Oxford University Press, Delhi.

Grujcic, I., Vojislav, M. \& Nonic, D. (2008): Conflict management in protected areas: The Lazar Canyon natural monument, Eastern Serbia. Int J. Biodivers Sci. Manage., 4; 221-229.

Hornsby, P.(1997): Records of birds seen at Brindana gorge, in the north flinder ranges,South Australia. South Aust.Ornithol,. 32:118-12.

Hubenov, Z. (2012): Estimation of the faunistic diversity of the Kresna Gorge. Historia Naturalis Bulgarica. 20:107-120.

Jalilovaa, G., Groot, J.D., \& Vacika, H.(2013): Evaluating the effects of habitats on birds in the walnut fruit forests: a case study from Kyrgyzstan. Biodiversity, 14 (2); 97-110.

Joshi, A.K., \& Bhatnagar, C.,(2015): The Diversity and Spatial Distribution of Birds in a Moderately Developed Urban Habitat of Gulabpura, Rajasthan, India: Int. Res. J. Environ.Sci., 4(12), 82-92.

Kopij, G.( 2013): Avian assemblages of river gorges in the Maloti/Drakensberg 'hot-spot' region, Southern Africa. 
Zool. Ecol., 23: 171-182.

Manchiryala, R., \& Medicheti, R.M. (2016): Breeding Biology of Critically Endangered Long-billed Vulture (Gyps indicus) at a Unique Site in Telangana State,India. Ambi.Sci.,03 (1):49-51

Mowbray, T.B. \& Henry, J.O. (1968): Vegetation Gradients in Relation to Environment and Phenology in a Southern Blue Ridge Gorge. Ecol. Monogr., 38:309-344.

Nikolov, S., \& Spasov, S.D. (2005): Frequency, Density and Numbers of some breeding birds in the south part of Kresna Gorge (SW Bulgaria). Acrocephalus 26: 273-282.

Parnell, J.F., \& Quay, T.L. (1964): The Summer Birds of The Toxway River Gorge Of Southwestern North Carolina. Wilson Bulletin. 76(2);138-146.

Patten, M.A., Reinking, D.L., \& Wolfe, D.H.(2006): Avifauna of the Four Canyon Preserve, Ellis County, Oklahoma. Publications of The Okalhama Biological Society, 2nd Series.

Puth, L.M., \& Wilson, K.A. (2001): Boundaries and corridors as a continuum of ecological flow control: lessons from rivers and streams. Conserv. Biol., 15; 21-30.

Quinn, C.H., Ndangalasi, H.J., Gerstle, J., \& Lovett, J.C. (2005): Effect of the Lower Kihansi Hydropower Project and post- project mitigation measures on wetland vegetation in Kihansi Gorge, Tanzania. Biodiver. Conserv. 14:297-308.

Rahmani, A.R.(2015): Threatened Birds of India.Publisher: BNHS and Oxford University Press.

Sharma, S.K., \& Singh, B.P. (2006): Birds of the gorges of Vindhyas in Rajasthan state. Zoos' Print. 21:2167-2169.

Shurulinkov, P. \& Nikolov, I. (2005): Recent status of the breeding avifauna in the canyons of Rousenski Lom River system, north-eastern Bulgaria. Ciconia.13:77-87

Singh, S. (2015): Geomorphology. Publisher:Pravalika Publications, Allahabad.pp 416-417.

Spanos, I., Panagiotis, P., Meliadis, I., \& Tsiontis, A. (2008): A review on the ecology and management of the Samaria Gorge, a Greek biosphere reserve. J.Geog. Reg. Plan. 1(2); 19-33.

Spence, J.R., Charles, T.L., \& John, D.G.. (2011): Birds of Glen Canyon National Recreation Area, Utah and Arizona. Monograph of the Western North American Naturalist 5: 207.

Taylor, D.M.(1989): Notes on Hells Canyon Birds.The Great Basin Naturalist 49 (2);279-287.

The IUCN Red List of Threatened Species, 2015. Version 2015-4. Available at www.iucnredlist.org. Accessed on o5 May 2016.

\section{Some Threatened Birds of Kekariya Gorge}
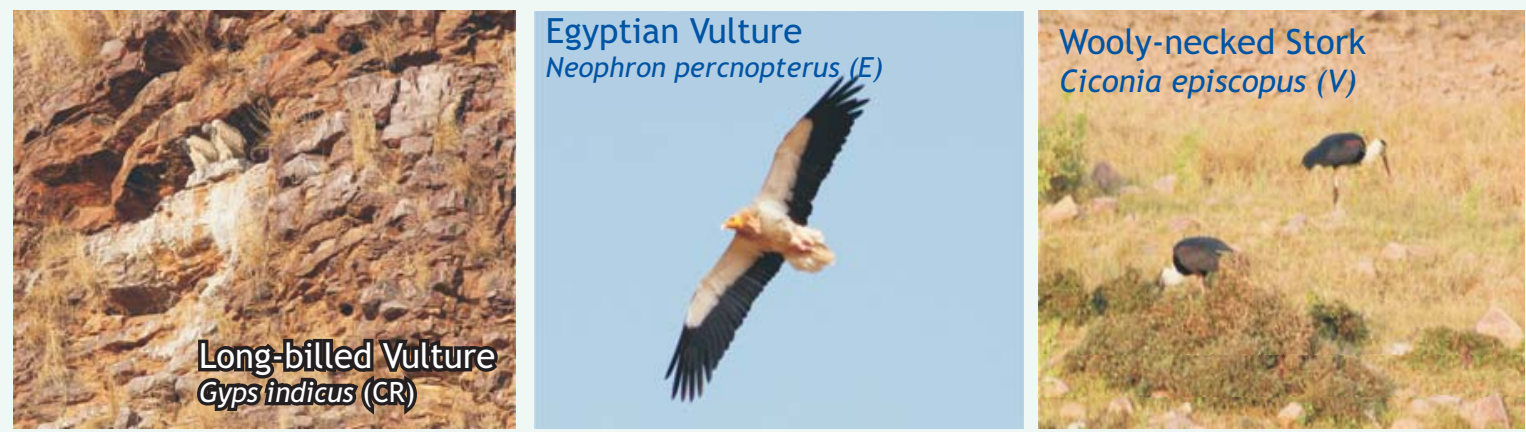

Table-1 Bird species recorded in the gorge of Kekariya (a Vindhyan gorge)

Common Name

Phasianidae

$\begin{array}{ll}1 & \text { Grey Francolin } \\ 2 & \text { Indian Peafowl } \\ 3 & \text { Painted Spurfowl } \\ \text { Ciconiidae } \\ 4 & \text { Woolly-necked Stork } \\ \text { Ardeidae } \\ 5 \quad \text { Indian Pond Heron } \\ 6 \quad \text { Little Egret } \\ \text { Phalacrocoracidae } \\ 7 & \text { Little Cormorant } \\ \text { Accipitridae } \\ 8 & \text { Egyptian Vulture } \\ 9 & \text { Indian or Long-billed vulture } \\ 10 & \text { Crested Serpent Eagle } \\ 11 & \text { Shikra } \\ 12 & \text { Eurasian Sparrowhawk } \\ 13 & \text { Bonelli's Eagle }\end{array}$

Zoological name

Francolinus pondicerianus

Pavo cristatus

Galloperdix lunulata

Ciconia episcopus

Ardeola grayii

Egretta garzetta

Phalacrocorax niger

Neophron percnopterus

Gyps indicus

Spilornis cheela

Accipiter badius

Accipiter nisus

Aquila fasciata

\section{Residential Feeding guild status}

$\begin{array}{cc}\mathrm{R} & \text { Omnivorous } \\ \mathrm{R} & \text { Omnivorous } \\ \mathrm{R} & \text { Omnivorous } \\ \mathrm{R} & \text { Carnivorous } \\ \mathrm{R} & \text { Carnivorous } \\ \mathrm{R} & \text { Carnivorous } \\ \mathrm{R} & \text { Carnivorous } \\ \mathrm{R} & \\ \mathrm{R} & \text { Carnivorous } \\ \mathrm{R} & \text { Carnivorous } \\ \mathrm{R} & \text { Carnivorous } \\ \mathrm{R} & \text { Carnivorous } \\ \mathrm{SM} & \text { Carnivorous } \\ \mathrm{R} & \text { Carnivorous }\end{array}$

Distribution IUCN

in the gorge status 
RESEARCH ARTICLE

\section{Common Name}

Scolopacidae

14 Common Sandpiper

Columbidae

15 Common Pigeon

16 Eurasian Collared Dove

17 Spotted Dove

18 Laughing Dove

19 Yellow footed green pigeon

Psittacidae

20 Rose-ringed Parakeet

21 Plum-headed Parakeet

Cuculidae

22 Jacobin Cuckoo

23 Common Hawk Cuckoo

24 Asian Koel

25 Southern Coucal

Strigidae

26 Indian Eagle-Owl

27 Spotted Owlet

28 Brown Fish-Owl

29 Mottled Wood-Owl

Apodidae

30 Little Swift

Coraciidae

$31 \quad$ Indian Roller

Alcedinidae

32 White-throated Kingfisher

Meropidae

33 Green Bee-eater

Upupidae

34 Common Hoopoe

Picidae

36 Lesser Golden-back Woodpecker Dinopium benghalense

37 Yellow-Crowned Woodpecker

Campephagidae

38 Large Cuckoo-shrike

39 Small Minivet

40 Common Woodshrike

41 Long-tailed Shrike

Oriolidae

42 Indian Golden Oriole

Dicruridae

44 White-bellied Drongo

Rhipiduridae

45 White-browed Fantail Flycatcher Rhipidura aureola

Monarchidae

46 Asian Paradise-flycatcher

Corvidae

Paridae

48 Great Tit

Hirundinidae

49 Wire-tailed Swallow

50 Dusky Crag Martin
35 Brown-capped Pygmy Woodpecker Dendrocopos nanus

43 Black Drongo

47 Rufous Treepie
Zoological name

Actitis hypoleucos

Columba livia

Streptopelia decaocto

Streptopelia chinensis

Streptopelia senegalensis

Treron phoenicopterus

Psittacula krameri

Psittacula cyanocephala

Clamator jacobinus

Hierococcyx varius

Eudynamys scolopaceus

Centropus sinensis

Bubo (bubo) bengalensis

Athene brama

Ketupa zeylonensis

Strix ocellata

Apus affinis

Coracias benghalensis

Halcyon smyrnensis

Merops orientalis

Upupa epops

Dendrocopos mahrattensis

Coracina macei

Pericrocotus cinnamomeus WM

Tephrodornis pondicerianus $\mathrm{R}$

Lanius schach

Oriolus oriolus

Dicrurus macrocercus

Dicrurus caerulescens

Terpsiphone paradisi

Dendrocitta vagabunda

Parus major

Hirundo smithii

Ptyonoprogne concolor
Residential Feeding guild status

WM Insectivorous

R Grainivorous

$\mathrm{R} \quad$ Grainivorous

$\mathrm{R} \quad$ Grainivorous

$\mathrm{R} \quad$ Grainivorous

$\mathrm{R} \quad$ Frugivorous

$\mathrm{R} \quad$ Frugivorous

$\mathrm{R} \quad$ Frugivorous

SM

SM

$\mathrm{R}$

$\mathrm{R}$

$\mathrm{R}$

$\mathrm{R}$

$\mathrm{R}$

$\mathrm{R}$

$\mathrm{R}$

$\mathrm{R}$

$\mathrm{R}$

Carnivorous

$\mathrm{R} \quad$ Insectivorous

$\mathrm{R}$

Insectivorous

Insectivorous

Insectivorous

Insectivorous

Insectivorous

Insectivorous

Insectivorous

Carnivorous

WM

Omnivorous

$\mathrm{R} \quad$ Insectivorous

$\mathrm{R} \quad$ Insectivorous

$\mathrm{R} \quad$ Insectivorous

WM

Insectivorous

$\mathrm{R}$

Omnivorous

R Omnivorous

$\mathrm{R}$

$\mathrm{R}$

Insectivorous
Ambient Science, 2016: Vol. 03(2); 55-60 DOI:10.21276/ambi.2016.03.2 ra01

Distribution IUCN

in the gorge status

IG LC

RG LC

RG LC

RG,IG LC

RG LC

RG LC

IG,RG LC

IG,RG LC

IG,RG LC

RG LC

RG LC

RG LC

IG LC

IG,RG LC

IG LC

IG LC

IG LC

RG LC

IG LC

RG LC

RG

RG LC

RG LC

RG LC

RG LC

IG LC

IG,RG LC

RG LC

IG LC

IG,RG LC

IG,RG LC

IG,RG LC

IG LC

IG LC

Ambient Science (2016)

http://www.caves.res.in/

IG,RG LC

IG LC

IG LC 
Common Name

51 Red-rumped Swallow

Alaudidae

52 Singing Bushlark

53 Ashy-crowned Sparrow-Lark

Cisticolidae

54 Ashy Prinia

55 Plane Prinia

56 Rufous-fronted Prinia

57 Common Tailorbird

58 Common Lesser Whitethroat

59 Common Chiffchaff

6o Sulphur-bellied Warbler

61 Green Warbler

Pycnonotidae

62 Red-vented Bulbul

Timaliidae

63 Common Babbler

64 Large Grey Babbler

65 Jungle Babbler

Sturnidae

66 Bank Myna

67 Common Myna

68 Asian Pied Starling

69 Brahminy Starling

Turdidae

70 Indian Robin

71 Brown Rock Chat

Muscicapidae

72 Grey-headed Canary Flycatcher

73 Tickell's Blue flycatcher

74 Red-breasted flycatcher

Nectarinidae

75 Purple Sunbird

Passeridae

76 Chestnut-shouldered Petronia

Estrildidae

77 White Throated Munia

Motacillidae

78 Yellow Wagtail

79 Grey Wagtail

Emberizidae

8o Crested Bunting

81 White-capped Bunting

82 Grey necked Bunting

Zoological name
Cecropis daurica
Mirafra cantillans
Eremopterix griseus
Prinia socialis
Prinia inornata
Prinia buchanani
Orthotomus sutorius
Sylvia curruca
Phylloscopus collybita
Phylloscopus griseolus
Phylloscopus trochiloides

Residential Feeding guild status

$\mathrm{R} \quad$ Insectivorous

R Omnivorous

$\mathrm{R}$ Omnivorous

$\mathrm{R} \quad$ Insectivorous

$\mathrm{R}$ Insectivorous

$\mathrm{R}$ Insectivorous

$\mathrm{R}$ Insectivorous

WM Insectivorous

WM Insectivorous

$\mathrm{R}$ Insectivorous

WM Insectivorous

Pycnonotus cafer

Turdoides caudate

Turdoides malcolmi

Turdoides striata

Acridotheres ginginianus

Acridotheres tristis

Gracupica contra

Sturnus pagodarum

Saxicoloides fulicatus

Cercomela fusca

Culicicapa ceylonensis

Cyornis tickelliae

Ficedula parva

R Omnivorous

$\mathrm{R}$ Omnivorous

$\mathrm{R} \quad$ Omnivorous

$\mathrm{R}$ Omnivorous

R Omnivorous

$\mathrm{R} \quad$ Omnivorous

$\mathrm{R} \quad$ Omnivorous

$\mathrm{R}$ Omnivorous

$\mathrm{R}$ Insectivorous

$\mathrm{R}$ Insectivorous

WM

WM

WM

Insectivorous

Insectivorous

Insectivorous

Nectarinia asiaticus

Gymnoris xanthocollis

Lonchura malabarica

Motacilla flava

Motacilla cinerea

Melophus lathami

Emberiza stewarti

Emberiza buchanani

$\begin{array}{clcc}\text { R } & \text { Nectivorous } & \text { RG,IG } & \text { LC } \\ \text { R } & \text { Omnivorous } & \text { RG } & \text { LC } \\ & & & \\ \text { R } & \text { Omnivorous } & \text { RG } & \text { LC } \\ & & & \\ \text { WM } & \text { Insectivorous } & \text { IG } & \text { LC } \\ \text { WM } & \text { Insectivorous } & \text { IG } & \text { LC } \\ & & & \\ \text { WM } & \text { Grainivorous } & \text { IG } & \text { LC } \\ \text { WM } & \text { Grainivorous } & \text { IG } & \text { LC } \\ \text { WM } & \text { Grainivorous } & \text { IG } & \text { LC }\end{array}$

Abbreviations- R- Resident, WM-Winter Migratory, SM- Summer Migratory, IG- In gorge, RG- Roof or Terrace of the gorge, LC- Least Concern,

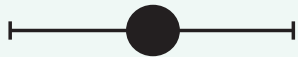

